\title{
Geothermal Hot Water and Space Heating System in Egypt
}

\author{
H. M. Farghally1, F. H. Fahmy1, and M. A. H.EL-Sayed2 \\ 1Electronics Research Institute, National Research Center Building, Cairo, Egypt \\ 2Center of Energy Studies, University of Trinidad and Tobago
}

\begin{abstract}
Direct utilization of geothermal energy refers to the immediate use of the heat energy rather than to its conversion to electrical energy. The primary forms of direct use include heating and cooling. Geothermal energy could be used to supply hot water or could be used with a special equipment (radiators) to make buildings warmer during winter seasons. In general, the geothermal fluid temperatures required for direct heat use are lower than those for economic electric power generation. Most direct use applications use geothermal fluids in the low-tomoderate temperature range between $50 \mathrm{o}$ and $150 \mathrm{oC}$. Although Egypt is not characterized by abundant igneous activity, its location in the northeastern corner of the African plate suggests that it possess geothermal resources, especially along its eastern margin. The data indicate that the temperature of 150 oC may be found in the reservoir in the gulf of Suez and red coastal zone. This work designs a geothermal hot water and space heating system to operate in three buildings in a remote area in the Eastern Desert (i.e. school, home \& emergency hospital ) and applies to the Umm Huweitat well(sample no. 69 on the Red Sea approximately $20 \mathrm{~km}$ north of the city of Safaga.) as a case study.
\end{abstract}

\section{Keywords}

Geothermal energy, production well, heat exchanger, radiator, water heater

\section{Introduction}

Geothermal energy is energy derived from the heat of the earth's core. It is clean, abundant, and reliable. If properly developed, it can offer renewable and sustainable energy source.After the Second World War many countries were attracted by geothermal energy, considering it to be economically competitive with other forms of energy. It did not have to be imported, and, in some cases, it was the only energy source available locally.Geothermal energy utilization is divided into electric energy production and direct uses. Direct utilization of geothermal energy consists of various forms for heating and cooling instead of converting the energy for electric power generation [1]. The major areas of direct utilization are: heating of swimming pools and for space heating and cooling including district heating; agriculture applications (greenhouse heating and crop drying); aquaculture applications; industrial processing; and geothermal heat pumps.

In general, the geothermal fluid temperatures required for direct heat use are lower than those for economic electric power generation. The geothermal resources in Egypt are in the lower temperature ranges that are more widespread than the higher temperature resources that may be found in the reservoir in the gulf of Suez and red coastal zone [2] .In this context, the proposed work presents and design a geothermal hot water and space-heating system designed to operate in three different buildings (i.e. school, home $\&$ emergency hospital) in a remote area in the Eastern Desert of Egypt.

\section{The Proposed Geothermal Hot Water and Space Heating System Components}

The block diagram of the geothermal hot water and space heating system is shown in Fig. 1. The diagram consists of a production facility (Umm Huweitat well (sample no. 69) throughout the Eastern Desert) to convey the heated water to the surface, a mechanical system (piping, pump, controls) to convey the heat energy to where it is required, a disposal system to receive the output fluid, a heat exchanger to minimize possible corrosion, scaling, or fouling of pipes, valves and other fittings in the system ,radiators to make buildings warmer during winter seasons and simple geothermal water heaters for supplying hot water.

\section{System Design}

The design and the selection of each component of the geothermal hot water and space heating system plays an important role in the system reliability, safety, cost and maintenance.Size, type and material of each component are the most important parameters, which should be considered .

A. Design of the space heating system 


\section{a. Space heating load calculation}

Before designing a heating system, one must estimate the amount of heat which is lost from the building. There are two sources of heat loss from a building fabric heat losses and ventilation heat losses. Fabric heat losses are losses directly through the walls, windows, doors, floors and ceiling of the room. For ease of calculation, it is assumed that these losses are at a uniform rate through each surface. The heat loss (Qf) rates are obtained by multiplying the area of each individual surface (As) by the design temperature difference (ti-to) and the heat transfer co-efficient called the ' $U$ ' Value. [3].

Thus;

$\mathrm{Q}_{\mathrm{f}}(\mathrm{k} . \mathrm{cal} / \mathrm{hr})=\mathrm{A}_{\mathrm{s}}\left(\mathrm{m}^{2}\right) *\left(\mathrm{t}_{\mathrm{i}}-\mathrm{t}_{\mathrm{o}}\right)\left({ }^{\mathrm{o}} \mathrm{C}\right)$

*' U'Value (k.cal/hrm $\left.{ }^{2} .{ }^{\circ} \mathrm{C}\right)$

Ventilation heat losses are caused by the air flowing through a building. Ventilation rates are usually quoted in air changes per hour. Defined as the volume of the air flowing through the room in one hour divided by the actual volume of the room itself. This air clearly needs to be heated by the space heating system and the heat required $(\mathrm{Qv})$ is calculated by multiplying the volume of the $\operatorname{room}(\mathrm{C})$ by the air change rate $(\mathrm{ACH})$, the temperature difference between outside and inside(ti-to) and by the heat capacity of air (HCA) [3].

Thus;

$\mathrm{Q}_{\mathrm{v}}(\mathrm{kcal} / \mathrm{hr})=\mathrm{C}\left(\mathrm{m}^{3}\right) * \mathrm{ACH} *\left(\mathrm{t}_{\mathrm{i}}-\mathrm{t}_{\mathrm{o}}\right)\left({ }^{\circ} \mathrm{C}\right)$

* HCA (kcal/ hr. $\left.{ }^{3}{ }^{\circ}{ }^{\circ} \mathrm{C}\right)$

b. Design of radiators

There are different types of radiators (i.e cast iron, steel and aluminum radiators). A summary of typical ratings for different types of radiators for a temperature difference, water to air, of 60
oC is included in Table 1 . These ratings may be corrected using Table 2 for $30 \mathrm{oC}$ as in case of our application.

The most commonly used type is the steel radiators. The particular merits of steel radiators result from their small mass and their comparatively narrow waterways. They are light to handle on a building site and respond quickly to temperature control. Two types are selected to be used in our application, the radiant panel type for small rooms and a tubular type for medium and large rooms.

Fig. 2 shows the two types. The heat load curves for the three buildings are put in the same diagram as shown in Fig.3.

\section{B. Design of Water heaters}

A small steel heat exchanger inside a stainless steel tank, as shown in Fig.4. transfers heat from the geothermal water to the domestic hot water The tank consists of steel cylindrical vessel insulated by a layer of $7 \mathrm{~cm}$ of glass wool and the other casing cover is aluminum. The daily hot water consumption for the three buildings is shown in Table 3 .

Water heating load level shown in Fig.5 is influenced by

- The equipment: The dimension and the load level of the distribution tanks, and the insulation of tanks

- The user activities and the habits related to the different activities (for how long, how much water one use). Table shows the hot water consumption for the three buildings and the corresponding maximum heat load. 


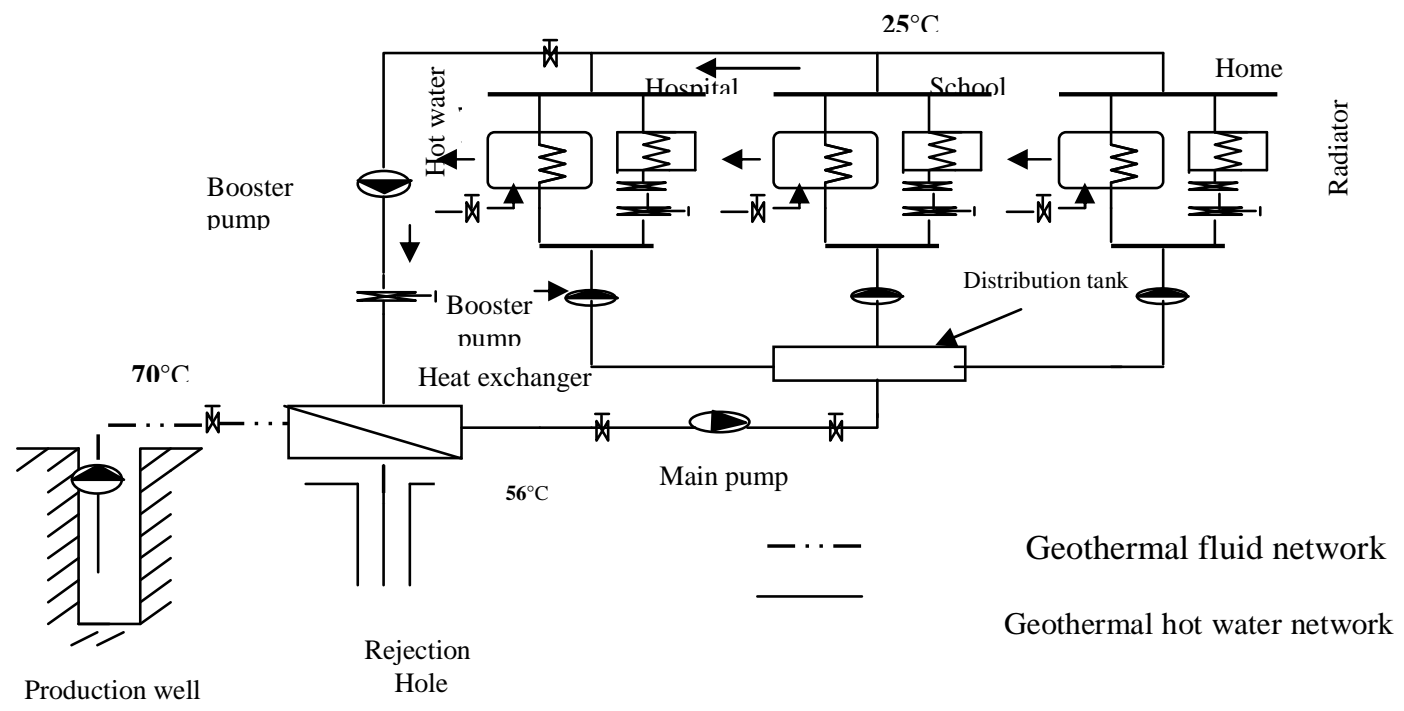

Fig.1 The geothermal hot water and space heating system

Table 1 Emissions from radiators for a temperature difference air to mean water of $60^{\circ} \mathrm{C}[4]$.

\begin{tabular}{|c|c|c|c|c|}
\hline \multicolumn{2}{|c|}{ Radiator } & \multicolumn{2}{|c|}{ Dimensions (mm) } & \multirow[b]{2}{*}{ 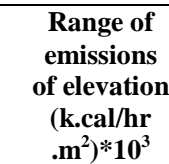 } \\
\hline Type & pattern & Depth & $\begin{array}{c}\text { Range of } \\
\text { heights }\end{array}$ & \\
\hline Cast iron sectional (open) & $\begin{array}{l}\text { 2- column } \\
\text { 4- column } \\
\text { 6- column }\end{array}$ & $\begin{array}{l}70 \\
160 \\
250\end{array}$ & $\begin{array}{l}430-980 \\
430-980 \\
280\end{array}$ & $\begin{array}{l}1.61-1.80 \\
2.93-3.08 \\
4.67\end{array}$ \\
\hline $\begin{array}{l}\text { Cast iron sectional (flat } \\
\text { front) }\end{array}$ & $\begin{array}{l}\text { 2- column } \\
\text { 4- column } \\
6 \text { - column }\end{array}$ & $\begin{array}{l}71 \\
161 \\
251\end{array}$ & $\begin{array}{l}430-980 \\
430-980 \\
280\end{array}$ & $\begin{array}{l}1.97-1.99 \\
3.45-3.5 \\
5.17\end{array}$ \\
\hline Radiant panel & & 35 & $500-900$ & $0.99-1.04$ \\
\hline Steel tubular with headers & $\begin{array}{l}40 \mathrm{~mm} \text { crs for } \\
\text { elements } \\
60 \mathrm{~mm} \text { crs for } \\
\text { elements }\end{array}$ & $\begin{array}{l}98 \\
166 \\
98 \\
166\end{array}$ & $\begin{array}{l}400-1000 \\
400-1000 \\
400-1000 \\
400-1000\end{array}$ & $\begin{array}{l}2.52-2.68 \\
4.44-4.55 \\
1.68-1.8 \\
2.95-3.04\end{array}$ \\
\hline $\begin{array}{l}\text { Aluminum sectional with } \\
\text { flat panel front }\end{array}$ & $\begin{array}{l}\text { Open top } \\
\text { Closed top }\end{array}$ & $\begin{array}{l}95 \\
160\end{array}$ & $\begin{array}{l}430-690 \\
285-435\end{array}$ & $\begin{array}{l}3.89-4.0 \\
5.74-5.79\end{array}$ \\
\hline $\begin{array}{l}\text { Aluminum finned unit in } \\
\text { casing }\end{array}$ & $\begin{array}{l}\text { With damper at } \\
\text { base }\end{array}$ & 30 & $300-750$ & $2.51-2.55$ \\
\hline
\end{tabular}


Table 2 Correction factors for power emitted from radiators [4].

\begin{tabular}{|c|c|c|c|c|c|c|c|c|c|c|}
\hline$\Delta \mathrm{t}\left({ }^{\circ} \mathrm{C}\right)^{1}$ & 0 & 1 & 2 & 3 & 4 & 5 & 6 & 7 & 8 & 9 \\
\hline 30 & 0.41 & 0.43 & 0.44 & 0.46 & 0.48 & 0.49 & 0.51 & 0.53 & 0.55 & 0.57 \\
\hline 40 & 0.59 & 0.61 & 0.63 & $0.65^{2}$ & 0.67 & 0.69 & 0.71 & 0.73 & 0.75 & 0.77 \\
\hline 50 & 0.79 & 0.81 & 0.83 & 0.85 & 0.87 & 0.9 & 0.92 & 0.94 & 0.96 & 0.98 \\
\hline 60 & 1.00 & 1.02 & 1.04 & 1.07 & 1.09 & 1.11 & 1.13 & 1.16 & 1.18 & 1.2 \\
\hline 70 & 1.23 & 1.25 & 1.27 & 1.30 & 1.32 & 1.34 & 1.37 & 1.39 & 1.41 & 1.43 \\
\hline 80 & 1.45 & 1.48 & 1.50 & 1.52 & 1.55 & 1.57 & 1.59 & 1.62 & 1.65 & 1.67 \\
\hline
\end{tabular}

1Temperature difference air to mean water

2 Correction factor at temperature difference $(\Delta \mathrm{t})=43^{\circ} \mathrm{C}$

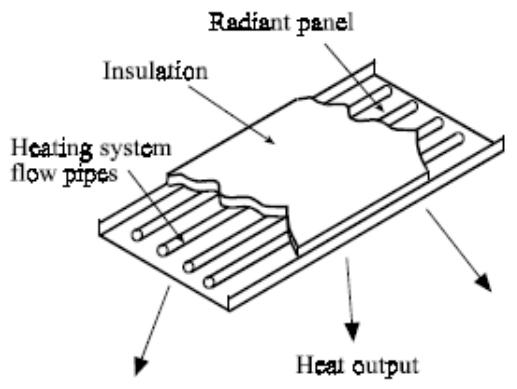

(a) Radiant panel.

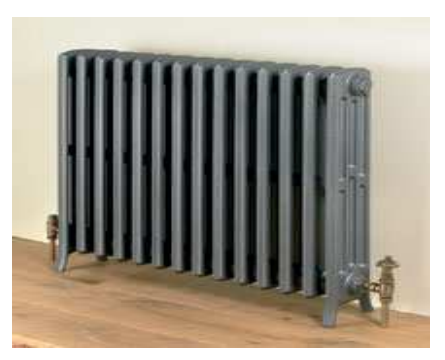

(b) Steel tubular with headers

Fig.2 Steel type radiators

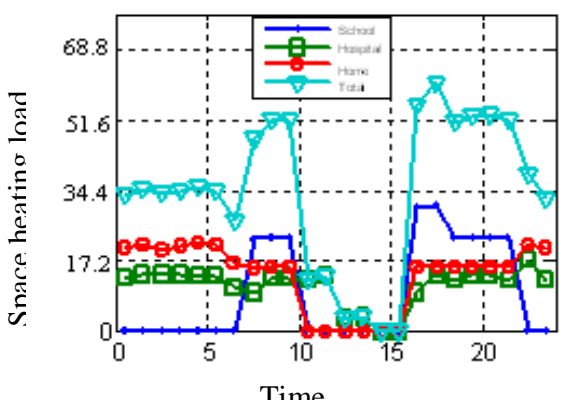

Fig.3 Estimated space heating load in three different buildings for one day in winter season
https://doi.org/10.24084/repqj08.728

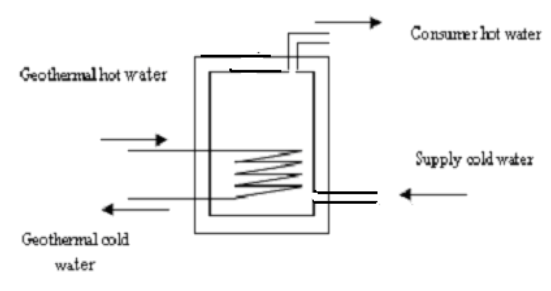

Fig. 4 Geothermal water heater.

Table 3 Daily hot water consumption for the three buildings

\begin{tabular}{|c|c|c|c|}
\hline Building & $\begin{array}{c}\text { No of } \\
\text { persons }\end{array}$ & $\begin{array}{c}\text { Hot water } \\
\text { consumption } \\
/ \text { person }\end{array}$ & $\begin{array}{c}\text { Total } \\
\text { consumption }\end{array}$ \\
\hline Home & $\begin{array}{c}5 \text { person } \\
* 8 \text { flat }\end{array}$ & 30 liter/day & 1200 liter/day \\
\hline Hospital & 30 & 30 liter/day & 900 liter/day \\
\hline School & 100 & 5 liter/day & 500 liter/day \\
\hline
\end{tabular}

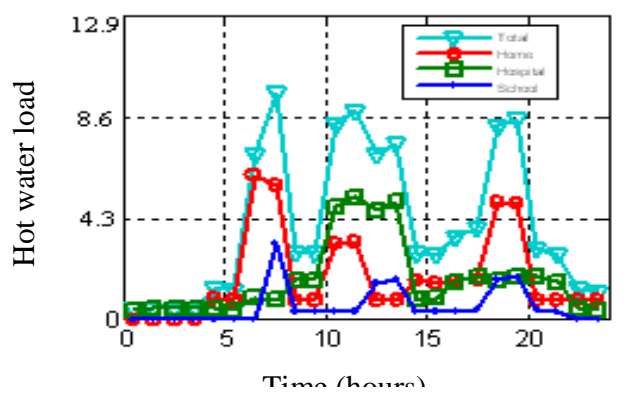

Fig. 5 Estimated hot water heating load in three different buildings for one day in winter season 


\section{Design of the Heat Exchanger}

Most geothermal fluids, because of their elevated temperature, contain a variety of dissolved chemicals. These chemicals are frequently corrosive toward standard materials of construction. As a result, it is advisable in most cases to isolate the geothermal fluid from the process to which heat is being transferred. The task of heat transfer from the geothermal fluid to a closed process loop is most often handled by a plate heat exchanger. The most common type used in geothermal applications is the brazed plate heat exchanger. A number of characteristics particularly attractive to geothermal applications are responsible for this. Among these are:

\section{Superior thermal performance}

2.Availability of a wide variety of corrosion resistant alloys.

\section{Ease of maintenance}

4.Expandability and multiplex capability

\section{Compact design}

As shown in Fig.6 (a), the plate heat exchanger is basically a series of individual plates pressed between two heavy end covers. The entire assembly is held together by the tie bolts. Individual plates are hung from the top carrying bar and are guided by the bottom carrying bar. For single-pass circuiting, hot and cold side fluid connections are usually located on the fixed end cover. Multi-pass circuiting results in fluid connections on both fixed and moveable end covers. The brazed plate unit as shown in Fig.6 (b) eliminates the end plates, bolts, and gaskets from the design. Instead, the plates are held together by brazing with copper. This results in a much less complicated, lighter weight and more compact heat exchanger.

The key parameter in the selection process is the heat transfer area required to accomplish this task. The general formula below describes this situation [5].

$\mathrm{Q}=\mathrm{U} * \mathrm{~A} * \mathrm{LMTD} * \mathrm{Cf}$

Where:

$\mathrm{Q}=$ Total heat load in $\mathrm{k} . \mathrm{cal} / \mathrm{hr}$

$\mathrm{U}=$ Overall heat transfer coefficient in

k.cal /hr.m2.oC

$\mathrm{A}=$ Area $(\mathrm{m} 2)$

\section{LMTD $=$ Log mean temperature difference (oC) \\ $\mathrm{Cf}=\mathrm{LMTD}$ correction factor $(0.85-1.0$ for most geothermal applications).}

The log mean temperature difference is calculated using the difference between the entering and leaving temperatures of the two fluids shown in Fig.6 (c) according to the following relationship

$$
\begin{aligned}
& \operatorname{LMTD}=\frac{\Delta \mathrm{t}_{1}-\Delta \mathrm{t} 2}{\ln \left(\frac{\Delta \mathrm{t}_{1}}{\Delta \mathrm{t}_{2}}\right)} \\
& \Delta \mathrm{t}_{1}=\mathrm{t}_{\text {out } 1}-\mathrm{t}_{\text {in } 2} \\
& \Delta \mathrm{t}_{2}=\mathrm{t}_{\text {in } 1}-\mathrm{t}_{\text {out2 }}
\end{aligned}
$$

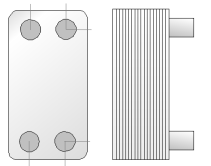

(a)The plate heat exchanger.

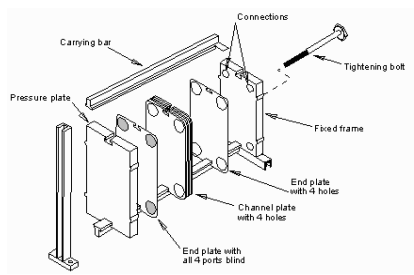

(b)Brazed plate heat exchanger

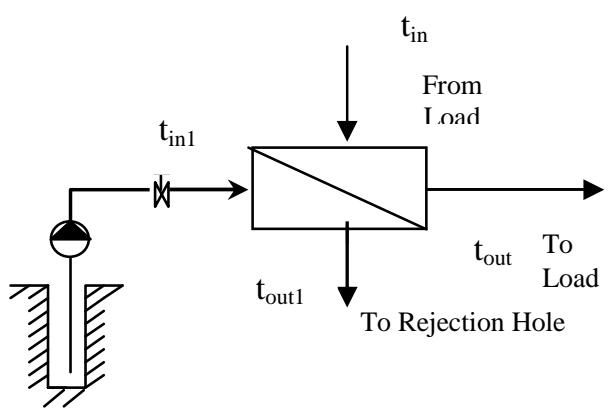

c)Entering and leaving temperatures of the two fluids.

Fig.6 The heat exchanger 
D. Hot Water and Space Heating System Design Procedure

The design of the proposed system is summarized in the following steps:

Step 1. determine the space heating load required for each room in the three buildings using Eqs. (1)\&(2)

Step 2. calculate the radiator heating area and radiotor dimensions using Tables $1 \& 2$

Step3 use the hot water consumption in each building illustrated in Table 3 to determine the hot water load and the water heater capacity in each building .

Step 4 use the value of the total heat load ( space heating load + water heating load) to calculate the heat transfer area required for the selected heat exchanger using Eqs (3),(4) \& (5)

\section{Results And Discussions}

The Specifications of different components of the geothermal hot water and space heating system are illustrated. Different specifications of the geothermal water heater are included in Table 4. The design heat loss calculations for the library in the school building as example are shown in Table5. The area, the complete dimensions of the selected radiators needed in each room and the corresponding heat load in the three building is shown in Tables 6,7 and 8 respectively.

\section{Conclusion}

The geothermal hot water and space heating system is the best and clean system to satisfy the energy needs in remote area buildings. We conduct a design analysis of the geothermal heating system components and apply to the Umm Huweitat well in eastern desert as a case study. The design parameters and specifications of each component are illustrated.

Table 4 Specifications of different constituents of the geothermal water heater.

\begin{tabular}{|c|c|}
\hline & Specification \\
\hline \multicolumn{2}{|l|}{ a- Hot water tank } \\
\hline - - Material & Stainless steel \\
\hline - - Volume & $\begin{array}{l}1200 \text { liter for home } \\
900 \text { liter for hospital } \\
500 \text { liter for school }\end{array}$ \\
\hline Dimensions & $\begin{array}{c}240 \mathrm{~cm} * 80 \mathrm{~cm} \text { for } \\
\text { home } \\
225 \mathrm{~cm} * 75 \mathrm{~cm} \text { for } \\
\text { hospital } \\
180 \mathrm{~cm} * 60 \mathrm{~cm} \text { for } \\
\text { school }\end{array}$ \\
\hline \multicolumn{2}{|l|}{ b-Insulation } \\
\hline Type & Glass wool \\
\hline $\begin{array}{l}\text { - Thermal } \\
\text { conductivity }\end{array}$ & $\begin{array}{l}9.024 * 10^{-3} \\
\text { k.cal/ hr.m }{ }^{\circ} \mathrm{C}\end{array}$ \\
\hline - $\quad$ Thickness & $7 \mathrm{~cm}$ \\
\hline - Density & $13 \mathrm{Kg} / \mathrm{m}^{2}$ \\
\hline c-Heat exchanger & steel \\
\hline
\end{tabular}

Table 5 Design heat loss calculations for the library in school building

\begin{tabular}{|c|c|c|c|c|c|c|c|c|c|}
\hline \multicolumn{10}{|c|}{ Fabric Heatloss } \\
\hline \begin{tabular}{|l|} 
Surface \\
\end{tabular} & & Area & & $\begin{array}{l}\text { Temperature } \\
\text { difference }\end{array}$ & & U Value & & Heat loss & Total \\
\hline & & $\mathrm{m}^{2}$ & & ${ }^{\circ} \mathrm{C}$ & & k.cal $/ \mathrm{hr} \mathrm{m}^{2} .{ }^{\circ} \mathrm{C}$ & & k.cal/hr & k.cal/hr \\
\hline \multicolumn{2}{|c|}{ External wall } & 41.58 & $\mathrm{x}$ & 14 & $\mathrm{x}$ & 0.791 & $=$ & 461 & \\
\hline \multicolumn{2}{|l|}{ Ceiling } & 36 & $\mathrm{x}$ & 14 & $\mathrm{x}$ & 1.393 & $=$ & 702 & \\
\hline \multicolumn{2}{|l|}{ window } & 4.32 & $\mathrm{x}$ & 14 & $\mathrm{x}$ & 4.3 & $=$ & 260 & \\
\hline \multicolumn{2}{|l|}{ Floor } & 36 & $\mathrm{x}$ & 14 & $\mathrm{x}$ & 0.31 & $=$ & 156 & 1579 \\
\hline \multicolumn{10}{|c|}{ Ventilation Heat loss } \\
\hline \begin{tabular}{c|} 
air \\
changes
\end{tabular} & & $\begin{array}{c}\text { Room } \\
\text { Volume }\end{array}$ & & $\begin{array}{l}\text { Temperature } \\
\text { difference }\end{array}$ & & $\begin{array}{l}\text { Heat capacity of } \\
\text { air }\end{array}$ & & Heat loss & \\
\hline number & & $\mathrm{m}^{3}$ & & ${ }^{\circ} \mathrm{C}$ & & k.cal $/ \mathrm{hr} . \mathrm{m}^{3} \cdot{ }^{\circ} \mathrm{C}$ & & watts & \\
\hline 1 & $\mathrm{x}$ & 118.8 & $\mathrm{x}$ & 14 & $\mathrm{x}$ & 0.284 & $=$ & 472 & 472 \\
\hline \multicolumn{9}{|c|}{ Total Design Heat loss } & 2051 \\
\hline
\end{tabular}


Table 6 Typical space heating load and radiator specifications for school building

\begin{tabular}{|c|c|c|c|c|c|c|c|c|}
\hline \multirow{2}{*}{$\begin{array}{c}\text { Room } \\
\text { Description }\end{array}$} & \multirow{2}{*}{$\begin{array}{l}\text { Room } \\
\text { area } \\
\left(\mathbf{m}^{2}\right)\end{array}$} & \multirow{2}{*}{$\begin{array}{c}\text { Estimate } \\
\text { d heat } \\
\text { load } \\
(\mathrm{kcal} / \mathrm{hr}) \\
* 10^{3}\end{array}$} & \multirow{2}{*}{$\begin{array}{c}\text { Design } \\
\text { heat load } \\
(\mathrm{kcal} / \mathrm{hr}) \\
* 10^{3}\end{array}$} & \multirow{2}{*}{$\begin{array}{c}\text { Radiator } \\
\text { Type }\end{array}$} & \multirow{2}{*}{$\begin{array}{c}\text { Heater } \\
\text { Area } \\
(\mathbf{m} 2)\end{array}$} & \multicolumn{3}{|c|}{ Radiator Dimensions (mm) } \\
\hline & & & & & & Depth & Length & Height \\
\hline $\begin{array}{l}\text { Mosque and } \\
\text { library }\end{array}$ & $6 * 6$ & 2.05 & 2.06 & $\begin{array}{l}\text { Steel tubular } \\
\text { with headers }\end{array}$ & 1.968 & 98 & 1968 & 1000 \\
\hline $\begin{array}{l}\text { Class rooms, } \\
\text { teacher rooms, } \\
\text { music room, and } \\
\text { computer room }\end{array}$ & $4.8 * 6$ & 1.78 & 1.806 & $\begin{array}{l}\text { Steel tubular } \\
\text { with headers }\end{array}$ & 1.722 & 98 & 1722 & 1000 \\
\hline Director room & $6 * 8$. & 2.347 & 2.322 & $\begin{array}{l}\text { Steel tubular } \\
\text { with headers }\end{array}$ & 2.214 & 98 & 2214 & 1000 \\
\hline Reception & $2.4 * 6$ & 0.959 & 0.946 & $\begin{array}{l}\text { Steel tubular } \\
\text { with headers }\end{array}$ & 0.902 & 98 & 902 & 1000 \\
\hline Center corridor & $2.4 * 6$ & 0.533 & 0.516 & $\begin{array}{l}\text { Steel tubular } \\
\text { with headers }\end{array}$ & 0.492 & 98 & 492 & 1000 \\
\hline Kitchen & $3 * 4.8$ & 0.96 & 0.946 & $\begin{array}{l}\text { Steel tubular } \\
\text { with headers }\end{array}$ & 0.902 & 98 & 902 & 1000 \\
\hline W.C. & $4.5 * 4.8$ & 1.255 & 1.29 & $\begin{array}{l}\text { Steel tubular } \\
\text { with headers }\end{array}$ & 1.23 & 98 & 1230 & 1000 \\
\hline $\begin{array}{l}\text { Right and left } \\
\text { corridors }\end{array}$ & $16 * 2.4$ & 1.652 & 1.634 & $\begin{array}{l}\text { Steel tubular } \\
\text { with headers }\end{array}$ & 1.558 & 98 & 1558 & 1000 \\
\hline
\end{tabular}

Table 7 Typical space heating load and radiator specifications for hospital building.

\begin{tabular}{|c|c|c|c|c|c|c|c|c|}
\hline \multirow{2}{*}{$\begin{array}{c}\text { Foom } \\
\text { Description }\end{array}$} & \multirow{2}{*}{$\begin{array}{l}\text { Foom } \\
\text { sres } \\
\left(m^{2}\right)\end{array}$} & \multirow{2}{*}{$\begin{array}{c}\text { Leinsted } \\
\text { hest bad } \\
\text { (heallhr) } \\
10^{3}\end{array}$} & \multirow{2}{*}{$\begin{array}{c}\text { Des igi } \\
\text { hest bad } \\
\text { (heallhr) } \\
{ }^{1} 10^{\prime}\end{array}$} & \multirow{2}{*}{$\begin{array}{l}\text { Radintor } \\
\text { Type }\end{array}$} & \multirow{2}{*}{$\begin{array}{c}\text { Hester } A \text { res } \\
(\mathrm{m} 2)\end{array}$} & \multicolumn{3}{|c|}{ Radintor Dmenis ins (mm) } \\
\hline & & & & & & Depth & Intgृth & Hegghit \\
\hline Foception & 642 & 135 & 1376 & $\begin{array}{l}\text { stool minhis } \\
\text { wifh lexilex }\end{array}$ & 1312 & 96 & 1312 & 1000 \\
\hline $\begin{array}{l}\text { Dontentionall } \\
\text { Ro viving roome }\end{array}$ & 642 & 1135 & 1115 & $\begin{array}{l}\text { Stolminhr } \\
\text { wifh lesiloxs }\end{array}$ & 1066 & 96 & 1066 & 1000 \\
\hline 5 西 $801 / 100010$ & 6.6 & 1537 & 1345 & $\begin{array}{l}\text { Stol trinhis } \\
\text { wifh lesidexs }\end{array}$ & $1 .+76$ & 96 & 1476 & 1000 \\
\hline $\begin{array}{l}\text { Tut axito CAIO } \\
\text { I0010 }\end{array}$ & 4245 & 1105 & 1115 & 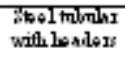 & 1066 & 98 & 1066 & 1000 \\
\hline 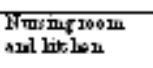 & 345 & 0Sজ & 0.602 & $\begin{array}{l}\text { Stolluiel } \\
\text { wifh coil }\end{array}$ & 1.449 & 35 & 160 & 900 \\
\hline Patouf 10001 & $4 S^{4}$ & 1372 & 1376 & $\begin{array}{l}\text { Stoolmbinh } \\
\text { wifh lesiloxs }\end{array}$ & 1312 & 96 & 1312 & 1000 \\
\hline 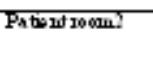 & $4 S^{4}$ & 1303 & 1290 & 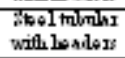 & 1230 & 98 & 1250 & 1000 \\
\hline Plangency & 3.45 & 12 & 1204 & $\begin{array}{l}\text { Btollninhi } \\
\text { wifh lesilons }\end{array}$ & 1145 & 98 & 1145 & 1000 \\
\hline $\begin{array}{l}\text { Batheome } 1 \\
\& 2\end{array}$ & 345 & 0.655 & 0.602 & $\begin{array}{l}\text { Stolpiol } \\
\text { wifh coil }\end{array}$ & $1.4+9$ & 35 & 160 & 900 \\
\hline E.506 Thion 100010 & 4245 & 0962 & 0956 & $\begin{array}{l}\text { Sholminhin } \\
\text { wifh lesilons }\end{array}$ & 0.902 & S6 & 902 & 1000 \\
\hline $5010,1 \& 2$ & 2.42 .4 & 0.279 & 0.53 & 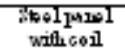 & 0.621 & 35 & 690 & 900 \\
\hline Hhin Gomblor & 3956 & $2 .+21$ & $2.40 \Omega$ & $\begin{array}{l}\text { Stool minhar } \\
\text { wifh lesiloxs }\end{array}$ & 2296 & 96 & 2296 & 1000 \\
\hline $\begin{array}{l}\text { Tabouhlay } \\
\text { comilor }\end{array}$ & 2.422 & 1536 & 1345 & $\begin{array}{l}\text { Stol monha } \\
\text { wifh lesiloxs }\end{array}$ & 1.476 & 96 & 1476 & 1000 \\
\hline Eintales & 3.645 & 035 & 0.602 & $\begin{array}{l}\text { Stol monhi } \\
\text { with lesilons }\end{array}$ & 0574 & 96 & 574 & 1000 \\
\hline
\end{tabular}


Table 8 Typical space heating load and radiator specifications for home building

\begin{tabular}{|c|c|c|c|c|c|c|c|c|}
\hline \multirow{2}{*}{$\begin{array}{c}\text { Room } \\
\text { Description }\end{array}$} & \multirow{2}{*}{$\begin{array}{l}\text { Room } \\
\text { area } \\
\left(\mathbf{m}^{2}\right)\end{array}$} & \multirow{2}{*}{$\begin{array}{c}\text { Estimated } \\
\text { heat load } \\
(\mathbf{k c a l} / \mathbf{h r}) \\
* 10^{3}\end{array}$} & \multirow{2}{*}{$\begin{array}{c}\text { Design } \\
\text { heat load } \\
(\mathrm{kcal} / \mathrm{hr}) \\
* 10^{3}\end{array}$} & \multirow{2}{*}{$\begin{array}{c}\text { Radiator } \\
\text { Type }\end{array}$} & \multirow{2}{*}{$\begin{array}{c}\text { Heater } \\
\text { Area } \\
\text { (m2) }\end{array}$} & \multicolumn{3}{|c|}{ Radiator Dimensions (mm) } \\
\hline & & & & & & Depth & Length & Height \\
\hline Bed room 1 & $3.6 * 4.2$ & 1.025 & 1.032 & $\begin{array}{l}\text { Steel tubular } \\
\text { with headers }\end{array}$ & 0.984 & 98 & 984 & 1000 \\
\hline Bed room 2 & $3.6 * 4.2$ & 0.839 & 0.860 & $\begin{array}{l}\text { Steel tubular } \\
\text { with headers }\end{array}$ & 0.820 & 98 & 820 & 1000 \\
\hline Bathroom & $2.4 * 2.4$ & 0.369 & 0.344 & $\begin{array}{c}\text { Steel panel } \\
\text { with coil }\end{array}$ & 0.828 & 35 & 920 & 900 \\
\hline Kitchen & $2.1 * 3$ & 0.514 & 0.516 & $\begin{array}{c}\text { Steel panel } \\
\text { with coil }\end{array}$ & 1.242 & 35 & 1380 & 900 \\
\hline Living room & $3.6 * 4.2$ & 0.764 & 0.774 & $\begin{array}{l}\text { Steel tubular } \\
\text { with headers }\end{array}$ & 0.738 & 98 & 738 & 1000 \\
\hline Corridor & $1.2 * 6$ & 0.713 & 0.688 & $\begin{array}{l}\text { Steel tubular } \\
\text { with headers }\end{array}$ & 0.656 & 98 & 656 & 1000 \\
\hline
\end{tabular}

Table 9 Plate heat exchanger design - parameters.

\begin{tabular}{|l|c|}
\hline \multicolumn{1}{|c|}{ Item } & Specification \\
\hline Type & \\
\hline Fouling factor & brazed plate heat exchanger \\
\hline $\begin{array}{l}\text { Resulting overall heat transfer } \\
\text { coefficient }\end{array}$ & 0.0001 to 0.0002 \\
\hline Heat transfer surface area $\left(\mathrm{m}^{2}\right)$ & $4443-5615 \mathrm{k} . \mathrm{cal} / \mathrm{hr} . \mathrm{m}^{2} .{ }^{\circ} \mathrm{C}$ \\
\hline Number of plates & 2.648 \\
\hline Plate material & 19 \\
\hline
\end{tabular}

\section{6.. References}

[1] J. W. Lund and D. H. Freeston, "Worldwide Direct Uses of Geothermal Energy 2000", Proceedings of the World Geothermal Congress 2000, Japan, 2000.

[2] C. A. Swanberg, P. Morgan and F.k. Boulos, "Geothermal Potential of Egypt,"

Tectonophysics; (Netherlands). vol.96, p.p. 77-94, 1983.

[3] F.C. McQuiston, J.D. Parker and J.D. Spitler, Heating, Ventilating, and Air Conditioning Analysis and Design, John Wiley \& Sons, USA, 2005

[4] P.L Martin and D.R.Oughton, Faber \& Kell's Heating and Air Conditioning of Buildings, Butterworth-Heinemann, England, 2002.

[5] K.Rafferty, Geothermal Direct-Use Engineering and Design Guidebook, Geo-Heat Center, Oregon Institute of Technology, Klamath Falls, OR. 1998 